\title{
DIGITALCOMMONS
}

@WAYNESTATE-

Wayne State University

4-1-2010

\section{The Pitfalls of Dealing with Witnesses in Public Corruption Prosecutions}

Peter J. Henning

Wayne State University, peter.henning@wayne.edu

\section{Recommended Citation}

Peter J. Henning, The Pitfalls of Dealing with Witnesses in Public Corruption Prosecutions, 23 Geo. J. Legal Ethics 351 (2010).

Available at: https://digitalcommons.wayne.edu/lawfrp/199

This Article is brought to you for free and open access by the Law School at DigitalCommons@WayneState. It has been accepted for inclusion in Law Faculty Research Publications by an authorized administrator of DigitalCommons@WayneState. 


\title{
The Pitfalls of Dealing with Witnesses in Public Corruption Prosecutions
}

\author{
Peter J. HenNing*
}

A faithful witness is one that will not lie, but a false witness launches forth mere lies. Proverbs 14:5

\section{INTRODUCTION}

Then Attorney General Michael Mukasey said in 2008 that " $[t]$ he investigation and prosecution of public corruption is among the highest obligations of law enforcement, and it should come as no surprise that I consider it to be one of the top priorities of the Department of Justice."1 These cases are significant not only because the defendants are usually leading public figures in cities and states, and sometimes on the national scene, but even more so because they involve a core value of our democratic form of government, that public authority cannot be used for private gain.

The importance of public corruption cases often is matched by the difficulty that prosecutors face in bringing them successfully because the government frequently relies on cooperating witnesses who were involved in highly questionable dealings. A number of recent prosecutions highlight the crucial role of the cooperating witness for the government's case and how that witness can bring a case down if the government is not careful. ${ }^{2}$ The prosecution of former Alaska Senator Ted Stevens on charges of filing false statements presented graphically the dangers a cooperating witness can pose if prosecutors are not careful.

Bill Allen, the former chairman of an Alaskan company, provided the critical

\footnotetext{
* Professor of Law, Wayne State University Law School. The author may be contacted at peter.henning@wayne.edu. I appreciate the comments and suggestions of Lee Radek, Esq., and Professors Bruce Green, Leonid Feller, Mark Armitage, and John Dolan on earlier drafts, and the usual fine editorial assistance of Olive Hyman.

1. U.S. Dep't of Justice, Fact Sheet: Dep't of Justice Public Corruption Efforts, (Mar. 27, 2008), http://www.justice.gov/opa/pr/2008/March/08_ag_246.html.

2. For example, the bribery investigation of former Congressman Randy "Duke" Cunningham, which resulted in his guilty plea and a 96-month sentence, was made in large part through the cooperation of lobbyist Mitchell Wade. See Greg Moran, Contractor in Scandal to Leam Fate Soon: Wade Cooperated in Cunningham Probe, San Diego Union-Trib., Dec. 14, 2008, at B 1.

The prosecution of former Illinois Governor Rod Blagojevich may be the rare comption case that does not need witness testimony to show a defendant's corrupt intent, although even here it would likely help the Department of Justice if it could put on testimony showing Blagojevich acting similarly in other situations.
} 
testimony about gifts given to the Senator that the Senator failed to report to the Senate. ${ }^{3}$ As often happens in corruption cases, Allen's story changed over time; however, prosecutors failed to disclose to the defense the star witness's exculpatory statements made during trial preparation, a due process violation under Brady v. Maryland. ${ }^{4}$ Months after a jury convicted the Senatorinstrumental in his narrow defeat at the polls shortly after the verdict-Attorney General Eric Holder announced that the government asked the court to drop the case due to the failure to disclose information about its key witness. ${ }^{5}$ A short time later, the Department of Justice asked that the convictions of two former Alaska state legislators also be reversed because of disclosure issues related to similar statements made by Allen in those cases. ${ }^{6}$

For prosecutors in public corruption cases, having someone who was "in the room" when the transaction occurred is crucial to establish the reason for offer or solicitation of a corrupt benefit. Such transactions involve a process that likely includes a number of interactions that may have taken place over weeks or even months. Government officials, particularly those in elective office, have numerous meetings and deal with a variety of constituencies, including lobbyists and campaign contributors. Separating out the ordinary intercourse of political life from the illicit transfer of benefits or money in exchange for the exercise of

3. See Richard Mauer \& Erika Bolstad, Close Friendship: Former Veco Boss Tells of Admiration For Senator, ANCHORAGE DaILy News, Oct. 1, 2008, at A1.

4. See Neil A. Lewis, Tables Turned on Prosecution in Stevens Case, N.Y. Times, Apr. 8, 2009, at A1 (discussing decision to dismiss charges against Senator Stevens because notes of an earlier conversation between a prosecutor and Allen were discovered that contradicted his trial testimony). In Brady v. Maryland, the Supreme Court held, "We now hold that the suppression by the prosecution of evidence favorable to an accused upon request violates due process where the evidence is material either to guilt or to punishment, irrespective of the good faith or bad faith of the prosecution." 373 U.S. 83, 87 (1963). The prosecution's Brady obligations are among the most fundamental requirements for a fair trial, and are frequently litigated, particularly in cases involving cooperating witnesses.

5. Attorney General Holder issued the following statement:

In connection with the post-trial litigation in United States $v$. Theodore F. Stevens, the Department of Justice has conducted a review of the case, including an examination of the extent of the disclosures provided to the defendant. After careful review, I have concluded that certain information should have been provided to the defense for use at trial. In light of this conclusion, and in consideration of the totality of the circumstances of this particular case, I have determined that it is in the interest of justice to dismiss the indictment and not proceed with a new trial.

Press Release, U.S. Dep't of Justice, Statement of Attorney General Eric Holder Regarding United States v. Theodore F. Stevens (Apr. 1, 2009), http://www.usdoj.gov/opa/pr/2009/April/09-ag-288.html. The district court granted the government's motion to dismiss, and the prosecutors assigned to the case are being investigated by the Office of Professional Responsibility in the Department of Justice.

6. In a statement reminiscent of what he said about the Stevens case, Attomey General Holder stated, "After a careful review of these cases, I have determined that it appears that the Department did not provide information that should have been disclosed to the defense." U.S. Dep't of Justice, Dep't Asks Alaska Corruption Cases Be Remanded to District Court, Former State Representatives Be Released (June 4, 2009), http://www.usdoj.gov/ opa/pr/2009/June/09-ag-550.html. Unlike in the Stevens case, however, the government did not request that the court dismiss the charges, but instead sought to have the case remanded to the district court to determine whether to allow a retrial of the charges. See id. 
government authority is almost impossible without a witness who was present. At the same time, a cooperating witness presents dangers because of the possibility of fabrication. ${ }^{7}$

All trial lawyers know the importance of witness preparation. As Professor Applegate pointed out, "American litigators regularly use witness preparation, and virtually all would, upon reflection, consider it a fundamental duty of representation and a basic element of effective advocacy." ${ }^{8}$ How far can a lawyer go, however, in preparing, or perhaps even "coaching," a witness by supplying information or suggesting responses that can shape the person's testimony so that it comes across well to the jury? The professional responsibility rules are largely silent on the issue of witness preparation and there are few judicial opinions on what is and is not acceptable in preparing a witness to testify. ${ }^{9}$

In this Article, I consider the meager guidance the various authorities on the professional responsibility of lawyers provide on the question of witness preparation. Each attorney must decide the issue for himself or herself because the interaction between counsel and witnesses will in all likelihood never be exposed to outside scrutiny; ${ }^{10}$ issues of privilege and the lack of any bright-line rules make it one the attorney must ultimately resolve. The question is not whether the lawyer can get away with allowing - or even encouraging — a client to present false testimony, but whether the lawyer will take the steps necessary to recognize when the potential for perjury exists and work to prevent its occurrence.

Part I outlines federal corruption statutes and highlights how the corrupt intent element is the central focus of the crime. ${ }^{11}$ The cooperating witness provides key testimony that can establish the public official's intent that cannot be shown easily from documents or other evidence. Part II discusses the importance of the

7. See Bennett L. Gershman, Witness Coaching by Prosecutors, 23 CARDozo L. Rev. 829, 847 (2002) ("The cooperating witness is probably the most dangerous prosecution witness of all. No other witness has such an extraordinary incentive to lie. Furthermore, no other witness has the capacity to manipulate, mislead, and deceive his investigative and prosecutorial handlers.").

8. John S. Applegate, Witness Preparation, 68 TEx. L. REv. 277, 278-79 (1989).

9. See id. at 279 ("The line between preparing and prompting (or 'coaching,' the usual term of opprobrium) is rarely clear even for the most scrupulous."). Professor Applegate describes witness preparation as "one of the dark secrets of the legal profession." Id.

10. See Richard C. Wydick, The Ethics of Witness Coaching, 17 CARDOzo L. REv. 1, 23 (1995) ("Lawyers typically interview and prepare witnesses in private surroundings, preferably in a quiet office with the door closed and with no strangers present. Because Grade One witness coaching [that results in the witness providing false testimony] is so obviously dishonest, no sensible lawyer would try it with a witness who might be inclined to report it, or in the presence of a third person who might be inclined to report it. Further, the work product immunity, and sometimes the attomey-client privilege, help shield conversations between lawyers and witnesses from probing by adversary counsel.").

11. See Rollin M. Perkins \& Ronald N. Boyce, Criminal Law 536-37 (3d ed. 1982) ("A corrupt intent is essential to guilt of bribery but it is important to keep in mind just what constitutes corruption in this regard . . . . On the part of the bribee, an intent to use the opportunity to perform a public duty as a means of acquiring an unlawful personal benefit or advantage, is a corrupt intent."). 
cooperating witness in a corruption case. Part III reviews the vague guidance provided by the legal ethics rules, noting how the broad proscription on introducing false testimony is of little aid in determining what is permissible in witness preparation. Part IV examines two particularly pertinent issues in public corruption cases for lawyers on both sides: the Brady disclosure obligation for prosecutors and the requirement to avoid perjured testimony, particularly by the defendant, for defense counsel. This Article concludes that the ethics rules provide little help to the attorneys, ultimately leaving it to the individual lawyer to ensure that the uncertain line between permissible preparation and creating false evidence is not crossed.

\section{Prosecuting Public Corruption}

Federal public corruption prosecutions can be brought under a range of statutes, from those sections that proscribe bribery and unlawful gratuities, ${ }^{12}$ to the Hobbs Act, which prohibits extortion "under color of official right,"13 to mail and wire fraud provisions that reach a scheme to defraud the victim of "the right of honest services." ${ }^{14}$ Although these statutes contain different elements, and a combination of them can be brought in a single indictment, the unifying theme among them is proving the defendant's intent to abuse government authority. In the criminal law parlance, these are "specific intent" crimes, which means that the jury must infer the defendant's particular state of mind at the time a benefit was received. ${ }^{15}$

What distinguishes public corruption prosecutions from other types of white collar crimes is the need to prove, in some fashion, that the defendant acted "corruptly" and did not simply engage in an accepted method of doing business. For example, section 201, which applies to federal and District of Columbia officials, and section 666, which applies to state and local governments, both explicitly require the government to prove that the defendant "corruptly" gave or accepted a bribe. ${ }^{16}$ The Supreme Court has interpreted the Hobbs Act's

12. 18 U.S.C. $\$ 201$ (bribery and unlawful gratuities for federal and District of Columbia officials); 18 U.S.C. $\$ 666$ (bribery and rewards for state and local officials, those working for programs receiving federal funding, and Indian tribal officials).

13. 18 U.S.C. \& 1951(a) and (b)(2) (prohibiting extortion "under color of official right").

14. 18 U.S.C. $\$ 1341$ (mail fraud); 18 U.S.C. $\$ 1343$ (wire fraud); 18 U.S.C. $\$ 1346$ (defining scheme to defraud to include the "intangible right of honest services").

15. In United States v. Sun-Diamond Growers of California, the Supreme Court explained that "for bribery there must be a quid pro quo-a specific intent to give or receive something of value in exchange for an official act." 526 U.S. 398, 404-05 (1999) (emphasis in original).

16. 18 U.S.C. $\S 201$ (b)(2) (Whoever "being a public official or person selected to be a public official, directly or indirectly, corruptly demands, seeks, receives, accepts, or agrees to receive or accept anything of value personally or for any other person or entity ..."); 18 U.S.C. $\$ 666(a)(1)(B)$ (Whoever "corruptly solicits or demands for the benefit of any person, or accepts or agrees to accept, anything of value from any person, intending to be influenced or rewarded in connection with any business, transaction, or series of transactions of such organization, government, or agency involving any thing of value of $\$ 5,000$ or more ..."). 
prohibition on extortion to incorporate bribery, requiring proof of a quid pro quo agreement that was corrupt and not a legitimate transaction, such as a campaign contribution. ${ }^{17} \mathrm{~A}$ scheme to defraud the public of the right of honest services owed by an official under the mail and wire fraud statutes covers a range of conduct, from bribery to kickbacks to misuse of office for personal gain, that require proof of an intent to gain from a violation of the person's fiduciary duty, meaning corruptly. ${ }^{18}$

The term "corruptly" does not have a fixed meaning and courts struggle to give it any more content than an imprecise reference to a defendant's contemptible state of mind. The Supreme Court in Arthur Andersen L.L.P. v. United States described "corruptly" as "normally associated with wrongful, immoral, depraved, or evil."19 In United States v. Rooney, the Second Circuit stated that "a fundamental component of a 'corrupt' act is a breach of some official duty owed to the government or the public at large." ${ }^{20}$ In United States $v$. Kelly, the same court upheld a jury instruction that defined "corruptly" as "to act with the intent to secure an unlawful advantage or benefit either for one's self or for another."21

\section{THE IMPORTANCE OF WITNESSES}

Showing an improper motive or desire to obtain an unlawful advantage is difficult to establish by way of documentary evidence. Perhaps more than any other area of white collar crime, the public corruption case requires the testimony of witnesses who can provide some insight into the defendant's knowledge of the impropriety of the transaction. Rarely will a document clearly establish that the offer of a benefit was given to obtain official action or that an official's statement was indeed the solicitation of a bribe and not simply a request for support or a campaign contribution. Especially in cases involving elected officials, the testimony of those who make the payments or facilitate the transfer-the intermediaries who surround every politician and the donors who appear with regularity - are usually the linchpin of the prosecution. ${ }^{22}$

17. See McCormick v. United States, 500 U.S. 257, 273 (1991) ("[I]f the payments to McCormick were campaign contributions, proof of a quid pro quo would be essential for an extortion conviction.").

18. See United States v. Sawyer, 85 F.3d 713, 730 (1st Cir. 1995) ("[A] bribery-like, corrupt intent to influence official action necessarily is an intent to deprive the public of an official's honest services."); United States v. Ring, 628 F. Supp. 2d 195, 213-14 (D.D.C. 2009) ("Ring's alleged awareness of congressional rules and his agreement to give gifts 'in exchange for' official action would demonstrate that he had the knowledge and corrupt intent necessary to violate the wire fraud statute.").

19. Arthur Andersen L.L.P. v. United States, 544 U.S. 696, 705 (2005).

20. United States v. Rooney, 37 F.3d 847, 852 (2d Cir. 1994).

21. United States v. Kelly, 147 F.3d 172, 177 (2d Cir. 1998).

22. For example, in the successful prosecution of former Louisiana Representative William Jefferson, a key witness was a cooperating witness who was videotaped paying the Congressman $\$ 100,000$, of which $\$ 90,000$ was later found hidden in a freezer in his home. See Jonathan Tilove, Guilty on 11 Counts, New ORLEANS TIMEs-PiCAyune, Aug. 6, 2009. 
The importance of witness testimony to the government's case often is matched by the need for the defense to put on witnesses to explain that no intent to corrupt the exercise of government authority existed. An important feature of the defense case will be to call into question those individuals who provided information to the government, showing that they misunderstood the interaction or, perhaps worse, fabricated their testimony to avoid responsibility. Frequently, the best witness is the defendant, but putting him on the witness stand is always a risky proposition even if almost a necessity in a public corruption prosecution. Especially when the defendant is an elected official, there is enormous pressure for the person to testify and explain how there was no corrupt motive, even where the transaction has the aura of impropriety. A failure to take the witness stand by a person whose political career involves taking - and explaining-public positions could be viewed as tantamount to an admission of the crime. Moreover, most politicians believe that if given the chance to explain themselves, they can convince a jury of their innocence. Under the professional responsibility rules, the client, not the lawyer, decides whether to testify, ${ }^{23}$ and the lure of the witness stand (and perhaps one last performance) can be overwhelming.

The central role of witnesses in the assessment of the meaning of "corruptly" means that the lawyers preparing them to testify play a particularly important role in the case. While the documents can provide crucial support for testimony, records are often ambiguous and rarely yield much insight into a defendant's state of mind. For the defense, the decision whether to put the defendant on the witness stand is frequently the most important issue in the trial because the defendant's testimony is often paramount in the jury's mind when it decides the case. Ensuring that the cooperating witness and the defendant are prepared for the onslaught of cross-examination can make the difference in a close case.

\section{The Ethics of Witness Preparation}

The rules of professional conduct say surprisingly little about the topic of witness preparation, even though they are designed to regulate significant aspects of the legal process. ${ }^{24}$ Courts recognize that witness preparation is common in all forms of litigation. As one district court noted:

[I]t could scarcely be suggested that it would be improper for counsel who called the witness to review with him prior to the deposition the testimony to be

23. Model Rules of Prof'l Conduct R. 1.2(a) (2007) [hereinafter Model Rules] ("In a criminal case, the lawyer shall abide by the client's decision, after consultation with the lawyer, as to a plea to be entered, whether to waive jury trial and whether the client will testify.").

24. See Joseph D. Piorkowski, Jr., Note, Professional Conduct and the Preparation of Witnesses for Trial: Defining the Acceptable Limitations of "Coaching", 1 Geo. J. LegAL ETHucs 389, 389 (1987) ("There remains, however, a vast realm of conduct that could potentially be characterized as improperly seeking to influence a witness' testimony. Within this area, there are very few guideposts to assist the attorney in maximizing his effectiveness as advocate while still remaining within the recognized limits of professional responsibility."). 
elicited. It is usual and legitimate practice for ethical and diligent counsel to confer with a witness whom he is about to call prior to his giving testimony, whether the testimony is to be given on deposition or at trial. ${ }^{25}$

Judges expect counsel for each side to have their witnesses ready to testify and to present the evidence in an orderly fashion. As the North Carolina Supreme Court stated:

It is not improper for an attorney to prepare his witness for trial, to explain the applicable law in any given situation and to go over before trial the attorney's questions and the witness' answers so that the witness will be ready for his appearance in court, will be more at ease because he knows what to expect, and will give his testimony in the most effective manner that he can. Such preparation is the mark of a good trial lawyer, and is to be commended because it promotes a more efficient administration of justice and saves court time. ${ }^{26}$

A lawyer is required to represent his or her client competently, and it likely would be viewed as malpractice for trial counsel to call an unprepared witness if there was a chance to meet and interview the person in advance, even if only for a few minutes. ${ }^{27}$ The District of Columbia Bar once stated in an ethics opinion, "a lawyer who did not prepare his or her witness for testimony, having had an opportunity to do so, would not be doing his or her professional job properly."28

At the other end of the spectrum, Model Rule 3.3(a)(3) states that a lawyer shall not "offer evidence that the lawyer knows to be false. If a lawyer, the lawyer's client, or a witness called by the lawyer, has offered material evidence and the lawyer comes to know of its falsity, the lawyer shall take reasonable remedial measures, including, if necessary, disclosure to the tribunal."29 The prohibition on introducing perjured testimony is clear, but whether a lawyer has allowed, or perhaps even led, a witness-including a client-to present false evidence is fairly uncommon, and the secrecy of witness preparation means it will rarely become known that a lawyer violated the rule by suggesting how a witness should testify in a way that is untruthful.

The issue of witness preparation sliding into falsity is, I suspect, rarely one of outright falsehood by the witness, when the person simply fabricates a story. Instead, the witness more likely will present his or her recall more clearly than in fact was the case before the lawyer suggested how to respond to questions; perhaps the opposite may happen as well, that the witness will respond "I don't

25. Hamdi \& Ibrahim Mango, Co. v. Fire Ass'n of Philadelphia, 20 F.R.D. 181, 182 (S.D.N.Y. 1957).

26. State v. McCormick, 259 S.E.2d 880,882 (N.C. 1979).

27. MODEL RULES R. 1.1 ("A lawyer shall provide competent representation to a client. Competent representation requires the legal knowledge, skill, thoroughness and preparation reasonably necessary for the representation."); see also Applegate, supra note 8, at 289 ("The obligation to prepare, in sum, is clear from the duties of competence and zealousness, however, the extent of that obligation is not clear.").

28. District of Columbia Ethics Op. No. 79 (Dec. 18, 1979).

29. Model Rules R. 3.3(a)(3). 
recall" when in fact the person does remember what occurred. Telling a witness what will play well before a jury could be benign, or it could be a means of changing the evidence to support one side's position.

The American Law Institute's Restatement (Third) of the Law Governing Lawyers addresses witness preparation explicitly and gives its imprimatur to a wide range of conduct that shapes a witness's testimony. Section 116(1) provides that "[a] lawyer may interview a witness for the purpose of preparing the witness to testify." ${ }^{30}$ This section appears to condone only a lawyer listening to what a witness has to say in an "interview," largely a passive exercise. Comment (b) to this section, however, goes on to provide a list of permissible steps the lawyer can take in preparing the witness that go far beyond merely interviewing the person about their testimony:

[D]iscussing the role of the witness and effective courtroom demeanor; discussing the witness's recollection and probable testimony; revealing to the witness other testimony or evidence that will be presented and asking the witness to reconsider the witness's recollection or recounting of events in that light; discussing the applicability of law to the events in issue; reviewing the factual context into which the witness's observations or opinions will fit; reviewing documents or other physical evidence that may be introduced; and discussing probable lines of hostile cross-examination that the witness should be prepared to meet. ${ }^{31}$

The Comment then states that "[w]itness preparation may include rehearsal of testimony" and that a "lawyer may suggest choice of words that might be employed to make the witness's meaning clear." ${ }^{32}$ Again, these steps are hardly the passive acts of interviewing a witness. Perhaps to assuage any fear that the Restatement is encouraging false testimony, the Comment ends with the careful admonition that "a lawyer may not assist the witness to testify falsely as to a material fact," but makes no effort to describe what the limits are on proper witness preparation. ${ }^{33}$

Under the Restatement's analysis, almost anything short of showing the witness how to commit perjury appears to be acceptable. Can the rules of the profession really take an "anything goes" approach so long as the lawyer does not assist the witness in presenting patently false testimony? It would be hard to find any type of preparation short of the lawyer instructing the witness to fabricate a story that would not be defensible under the Comment to section 116.

Consider a session in which a lawyer and witness rehearse the testimony that will occur the next day. Professor Applegate raises the issue of whether this type

30. RESTATEMENT (THIRD) OF THE LAW GOVERNING LAWYERS § 116(1) (2000).

31. RESTATEMENT (THIRD) OF THE LAW GOVERNING LAWYERS $\$ 116$ (b) cmt. II (b) (2000) (emphasis added).

32. Id. (emphasis added).

33. Id. 
of preparation undermines the truth-seeking function of a trial:

Rehearsal is in a sense the ultimate witness-preparation technique. It treats the trial precisely as a play scripted by the lawyers. Rehearsal goes beyond providing factual information or documents to familiarize the witness with the subject matter of the upcoming testimony. It is more intensive than simply providing demeanor suggestions. Most important, it comes uncomfortably close to the line between the lawyer's knowing what would help the case and the lawyer's advising the client how to help the case. ${ }^{34}$

As is typical in this and many other areas of legal ethics, the line between proper and improper conduct is so close as to be almost imperceptible. Professor Wydick noted that rehearsing testimony may be ethical or unethical, depending on the lawyer's (and the witness's) motivation:

Witness preparation sessions often end with role playing by the lawyer and witness. Typically, the lawyer questions the witness on several topics using the style she will use during direct examination. Then she, or one of her colleagues, cross-examines using the style the adversary lawyer is likely to use. If the purpose of role playing is merely to accustom the witness to the rough and tumble of being questioned, then it is ethically unobjectionable. If, however, the lawyer uses the role playing session as an occasion for scripting the witness's answers, then it is unethical. ${ }^{35}$

There is no clear external or objective indicator about when a particular form of witness preparation is unethical and when it is perfectly consistent with the lawyer's responsibility to competently represent a client and seek a lawful objective. Thus, lawyers are left on their own to determine whether their preparation of a witness is taking them close to the line of Model Rule 3.3's prohibition on false evidence.

\section{Preparing Witnesses and Clients to Testify}

A 1979 District of Columbia Bar ethics opinion issued, interpreting the now largely defunct Disciplinary Rules, highlights that the lawyer is responsible for determining when the line between permissible preparation and impermissible creation of false evidence has been crossed. ${ }^{36}$ The Opinion states that "it is not, we think, a matter of undue difficulty for a reasonably competent and conscientious lawyer to discern the line of impermissibility, where truth shades into untruth, and to refrain from crossing it." ${ }^{37}$ Would that life were so easy for

34. Applegate, supra note 8, at 323.

35. Wydick, supra note 10 , at 16 .

36. District of Columbia ETHICs OP. No. 79, supra note 28.

37. Id. 
lawyers that they could always discern the lines. ${ }^{38}$

Public corruption cases are about the intent of the offeror and recipient, and a jury must decide whether the reason for the transaction entailed the intentional misuse of government authority for personal gain. Whether the case involves gifts or other benefits to an official, or payments that may be campaign contributions, the determination of what was in the minds of the partieswhether the conduct was "corrupt"-will usually determine whether a guilty verdict is returned. For the prosecution, its key witness on this issue is likely to be a person who has agreed to cooperate in the case, often in exchange for a reduced sentence or, less frequently, a grant of immunity. For the defense, the public official's testimony will be crucial to the case because he is usually the only person who can explain what was understood about the relationship that is alleged to be corrupt.

Among the many temptations an attorney may face in trying a case, two in the public corruption case should be highlighted: (a) for the government, how much the prosecutor can shape the testimony of a cooperating witness to make it effective yet fulfill the obligation to ensure that the truth be ascertained and the due process rights of the defendant be respected; and (b) for either side, what to do when the witness testifying at trial suddenly adds facts or strengthens the recall of events beyond what was discussed during preparation; in other words, determining when does testimony become false under Model Rule 3.3.

\section{A. PREPARING THE COOPERATING WITNESS AND THE BRADY DISCLOSURE OBLIGATION}

Preparing a witness, especially the one who will directly accuse the defendant of engaging in criminal conduct, is of the utmost importance in a criminal case. Unlike the typical eyewitness, however, the cooperating witness in a public corruption case is not going to describe the crime like the victim of a robbery or observer of a drug deal testifies about a sequence of observable events and the identity of the perpetrators. In bribery and kickback cases, like most white collar criminal prosecutions, there is usually no real dispute regarding the facts of the underlying transaction. It is often conceded that the payment was made or the benefit conferred, and then that a governmental decision was implemented (or deferred).

The recall about the details of the events or physical characteristics of the perpetrator is not what is important; the intent of the participants in the process is

38. See W. William Hodes, The Professional Duty to Horseshed Witnesses-Zealously, Within the Bounds of the Law, 30 TEx. TECH L. REv. 1343, 1349 (1999) ("But how do we know when the result of a session in the horse shed [with a witness] is refreshing recollection, and when it is prompting perjury?"); Charles Silver, Preliminary Thoughts on the Economics of Witness Preparation, 30 TEx. TECH L. REv. 1383, 1383 (1999) ("Everyone knows that it is wrong to ask a witness to lie. What is not known is how far a lawyer can properly push a witness short of that."). 
key. While there may be some dispute about what was said between the parties, the issue is really one of what each side understood, and whether the public official misused the authority conferred by public office. The decision at issue need not be shown to be incorrect, and it is not a defense to a public corruption prosecution to argue that the act was outside the public official's authority or would have occurred regardless of the personal benefit. ${ }^{39}$

A cooperating witness has likely gone through two rounds of intense preparation before testifying at trial. First, the defense lawyer for the witness will have to prepare him or her for sessions with the prosecutors before the final decision is made to enter into the plea agreement, called "woodshedding" or "horseshedding" the witness. ${ }^{40}$ Prosecutors are fond of saying they will not buy "a pig in a poke," so they need to preview the person to ascertain whether he or she will be a good witness and can provide the type of information that will advance the case. ${ }^{41}$ Second, after the deal is made, the prosecutor has to prepare the witness for trial and determine how best to present a witness who made a deal and thus will be subject to a strong cross-examination attempting to show that the testimony is a fabrication to mitigate the witness's potential prison sentence-the "deal with the devil" problem.

In all of these rounds of preparation, the witness's testimony will be shaped by defense lawyers and prosecutors who will want the person to say certain things and describe the process in a way that will be favorable to showing the defendant's corrupt intent. The meaning of phrases and the types of gestures made by the recipient of a bribe or the public official seeking a kickback on a contract will be crucial. The case is not only a matter of "who said what when?" but also "what did you understand that to mean?" and "was the person hostile or friendly, cajoling or demanding?" Over time, the cooperating witness may adopt the viewpoint of the prosecutors, perhaps seeing more in the transaction than

\section{See United States v. Gjieli, 717 F.2d 968, 976 (6th Cir. 1983):}

The deterrent value of punishing the bad intent of bribers is the same regardless of whether or not the acts to be accomplished are within the scope of the actual lawful duties of the bribed public official and regardless of whether the briber has correctly perceived the precise scope of the official's lawful duties.

40. See Bruce H. White \& William L. Medford, The Pitfalls of Preparing a Lay Witness for Trial, 23 AM. BANKR. INST. J. 22, 52 (June 2004) ("The best method of finding out how a witness will testify, and exactly what he/she will say, is a good, old-fashioned woodshed session-essentially, talking to the witness alone so that the witness's attention is focused on trial preparation."); Hodes, supra note 38, at 1366 ("Arming the client with pertinent legal information and trusting the client to make good and legitimate use of it demonstrates loyalty and zealousness. Recognizing that at some point a loyal servant can be manipulated into becoming an accomplice in crime is honoring the bounds of law. And knowing how to flirt with that boundary line but not cross over it is true professionalism.").

41. See John G. Douglass, Confronting the Reluctant Accomplice, 101 Colum. L. REv. 1797, 1833 (2001) ("In the American system, witness preparation is an art form. American prosecutors are among its most practiced and capable artists. Cooperating accomplices receive much of their artistic attention."). 
really occurred at the time.$^{42}$ Frequently, public corruption cases get to trial years after the transactions at issue, and so memories may be tainted by the unintended bias of a witness who wants to be accommodating to the prosecution, perhaps reflecting the desire to have your side win the case.

For the prosecutor, there are competing pressures in pursuing the case. Convinced by evidence purportedly showing a legal violation that can be proven beyond a reasonable doubt, the prosecutor's focus becomes winning the case. Public corruption cases involve the core values of a democratic society: fair and equal treatment of all, and the punishment of abuse of government power so that our political institutions can function properly. ${ }^{43}$ Thus, achieving a conviction takes on even greater importance because of the political and social implications of corruption. At the same time, the admonition of the Supreme Court in Berger v. United States to prosecutors remains particularly relevant, cautioning that "while he may strike hard blows, he is not at liberty to strike foul ones. It is as much his duty to refrain from improper methods calculated to produce a wrongful conviction as it is to use every legitimate means to bring about a just one."44

Among the most important obligations of a prosecutor is to furnish exculpatory evidence to a defendant. In Brady v. Maryland, the Supreme Court held that "the suppression by the prosecution of evidence favorable to an accused upon request violates due process where the evidence is material either to guilt or to punishment, irrespective of the good faith or bad faith of the prosecution." ${ }^{45}$ In Giglio v. United States, the Court included within the Brady disclosure requirement impeachment information if the reliability of the witness may be determinative of the defendant's guilt. ${ }^{46}$

The disclosure obligation imposed by Brady and Giglio is familiar to all prosecutors. When getting a witness ready for trial, however, the line between permissible preparation and impermissible influence that may lead to false testimony is difficult to discern. A prosecutor would be unlikely to ask the witness to commit perjury, and the prohibition on such conduct is clear under both the

42. See United States v. Meinster, 619 F.2d 1041, 1045 (4th Cir. 1980) ("We think it obvious that promises of immunity or leniency premised on cooperation in a particular case may provide a strong inducement to falsify in that case."); Douglass, supra note 41 , at 1833 ("In sum, when we assess reliability, there is no reason to favor the live testimony of a cooperating accomplice over a blame-shifting jailhouse confession on the basis of the incentives which may shape, and shade, the accomplice's story. If anything, the incentive to favor the government is stronger by the time the accomplice finds his way to the witness stand.").

43. See Susan Rose-Ackerman, The Political Economy of Corruption, in Corruption and the Global ECONOMY (Kimberly Ann Elliott ed., 1997), at 31, 45 (Bribery "undermines the legitimacy of governments, especially democracies .... Citizens may come to believe that the government is simply for sale to the highest bidder. Corruption undermines claims that government is substituting democratic values for decisions based on ability to pay. It can lead to coups by undemocratic leaders.").

44. Berger v. United States, 295 U.S. 78, 88 (1935).

45. Brady v. Maryland, 373 U.S. 83, 87 (1963).

46. Giglio v. United States, 405 U.S. 150, 154 (1972). 
professional responsibility rules and Supreme Court precedent. ${ }^{47}$ But the shaping of a witness's testimony may itself raise questions about the scope of the witness's recollection and provide a basis to impeach the witness. Under Brady, this evidence would have to be disclosed to the defense. The prosecutor who comes close to the line of suggesting how a cooperating witness should testify or correcting perceived errors so that the testimony is consistent with other aspects of the government's evidence may not violate Model Rule 3.3 prohibition on presenting false testimony, but the information could come within the due process requirement for the government to disclose material exculpatory evidence to the defense. ${ }^{48}$

The interplay between the cooperating witness and the prosecutor often occurs outside the presence of a third party, such as counsel for the witness or case agents who may write a report of the preparation session. ${ }^{49} \mathrm{~A}$ witness interview during an investigation usually results in a report of some kind that can be turned over to the defense under Brady or as a Jencks Act statement, while pre-trial preparation often involves just the witness and government attorney. The prosecutor has discretion to keep the sessions with the witness within the bounds of propriety and to disclose any exculpatory information that might come out of the preparation process. ${ }^{50} \mathrm{Brady}$ is not limited to written materials, so an oral statement of a cooperating witness must be disclosed if it is exculpatory. Is that being done by prosecutors? ${ }^{51}$

\section{B. THE WITNESS WHO DOES BETTER THAN EXPECTED}

The issue of witness perjury is not a new one, and the professional responsibility rules make it clear that a lawyer cannot allow a witness, including a client, to present false testimony and must take steps to remedy the situation if it

47. See Napue v. Illinois, 360 U.S. 264, 271 (1959) (explaining that a new trial is required whenever false testimony could "in any reasonable likelihood have affected the judgment of the jury").

48. The Department of Justice issued a memorandum on January 4, 2010, Guidance for Prosecutors Regarding Criminal Discovery, that states,

Trial preparation meetings with witnesses generally need not be memorialized. However, prosecutors should be particularly attuned to new or inconsistent information disclosed by the witness during a pre-trial witness preparation session. New information that is exculpatory or impeachment information should be disclosed consistent with the provisions of USAM $\$ 9-5.001$ even if the information is first disclosed in a witness preparation session.

Memorandum from David W. Ogden, Deputy Attorney General on Guidance for Prosecutors Regarding Criminal Discovery (Jan. 4, 2010) http://www.justice.gov/dag/discovery-guidance.html.

49. There are prosecutors who will only meet with a potential witness in the presence of a third party, such as a case agent, to limit possible claims of improper conduct in the meeting.

50. See Department of Justice Memorandum, supra note 48.

51. See Gershman, supra note 7, at 834 ("[T] preparation of witnesses encourages improper coaching by hiding the process from meaningful oversight by courts or defense counsel."). 
does occur. ${ }^{52}$ The much harder issue of what the defense lawyer must do when the client-defendant intends to testify falsely has been the subject of significant debate in both the courts and the academic literature. ${ }^{53}$ As the Supreme Court noted in the leading case of Nix v. Whiteside, "[w]hatever the scope of a constitutional right to testify, it is elementary that such a right does not extend to testifying falsely." 54

It should be clear to anyone who reads Nix that the case was easy to decide because the Court essentially adopted the viewpoint of the defense lawyer, Gary L. Robinson, who had concluded that his client planned to commit perjury in his trial testimony to support a self-defense claim to a murder charge. As summarized in Nix:

Until shortly before trial, Whiteside consistently stated to Robinson that he had not actually seen a gun, but that he was convinced that Love had a gun in his hand. About a week before trial, during preparation for direct examination, Whiteside for the first time told Robinson and his associate Donna Paulsen that he had seen something "metallic" in Love's hand. When asked about this, Whiteside responded: “[I]n Howard Cook's case there was a gun. If I don't say I saw a gun, I'm dead."

Mr. Robinson's determination that his client intended to commit perjury occurred in the course of preparing him to testify at his murder trial, and the effort to dissuade Nix from committing perjury complied fully with the rules of the profession. As the Court noted,

[w] hether Robinson's conduct is seen as a successful attempt to dissuade his client from committing the crime of perjury, or whether seen as a 'threat' to withdraw from representation and disclose the illegal scheme, Robinson's representation of Whiteside falls well within accepted standards of professional conduct and the range of reasonable professional conduct acceptable under Strickland [v. Washington] ${ }^{56}$

Nix presents a stark example of potential client perjury when the defendant wanted to add a critical fact to his eyewitness testimony that would add

52. MOdEL Rules R. 3.3(a)(3).

53. The classic article on this issue is Monroe H. Freedman, Professional Responsibility of the Criminal Defense Lawyer: The Three Hardest Questions, 64 Mich. L. Rev. 1469 (1966). The California Court of Appeals reviewed the various approaches to client perjury in People v. Johnson. $72 \mathrm{Cal}$. Rptr. $2 \mathrm{~d} 805$ (Cal. Ct. App. 1998).

54. Nix v. Whiteside, 475 U.S. 157, 173 (1986) (emphasis in original).

55. Id. at 160-61. As happens with criminal defendants, the suggestion of a fellow prisoner-perhaps $\mathrm{Mr}$. Cook himself-is taken as the requisite for a successful defense.

56. Id. at 171. The issue in Nix was whether Robinson provided ineffective assistance of counsel in stating that he would withdraw and inform the court should the defendant testify falsely. The Court's statement that he came "well within accepted standards of professional conduct" is about as high a compliment as can be paid to an attorney in this context. Id. 
significant weight to the self-defense argument for acquittal. In public corruption cases, the focus on intent, which is usually inferred from an array of evidence, means that any false testimony is unlikely to be as clearly probative as Nix's potential perjury. For example, the meetings between a public official and a lobbyist and any transfer of money or other benefits are likely to be established by records, so the likelihood that a witness would fabricate testimony to create a meeting or bribe that did not occur is unlikely. The greater possibility for false testimony is more a matter of the nuances of the interactions, such as whether an official demanded a payment or merely made a vague suggestion, a distinction that may reflect as much tone or inflection as the words themselves. Moreover, the strength of the witness's recall of the details of the meeting that support the recollection can strengthen (or diminish) the veracity of the testimony.

For the prosecutor and the defense lawyer in the public corruption prosecution, the case that is far harder than Nix is when the witness or defendant adds new information during the testimony that may strengthen his or her credibility. ${ }^{57}$ It could be testimony about a statement made by the official that had not been mentioned before, or a disclaimer of knowledge regarding a transaction that was discussed during preparatory sessions. Unlike the "something 'metallic"' in Nix, the testimony may not be clearly false, or it may be just one piece of a much

57. The defense lawyer for the person who is trying to make a deal with the government by cooperating in its investigation can face a similar issue if the client adds details to strengthen the case against another target of the investigation. Unlike the client or witness testifying at trial, there is no public exposure of the statements, only the presence of the defense lawyer to ensure that it is correct. The attorney is in a difficult position when the client is proffering information to the govemment in the hope of receiving a plea bargain with reduced charges and a lower punishment because the better the information the greater the government's incentive to make a deal. The lawyer must be particularly attuned to any "enhancement" of the information being provided by the client because false statements could in fact scuttle a plea agreement and lead the government to prosecute the witness. This can create a sufficient counterbalance to reduce the cooperating witness's incentive to lie.

The danger of a cooperating witness committing perjury was shown in United States $v$. Wallach, when the Second Circuit overturned the convictions of the defendants because a witness (Guariglia), described as the "centerpiece" of the prosecution, lied about his continuing gambling after denying on the witness stand that he had done so. 935 F.2d 445, 457 (2d Cir. 1991). The circuit court found that the government did not know the witness was committing perjury during the trial, but the witness's improbable explanations about taking cash advances from casinos were sufficiently suspicious to undermine his credibility and required prosecutors to investigate his possible gambling further. $I d$. The court explained:

Guariglia was the centerpiece of the government's case. Had it been brought to the attention of the jury that Guariglia was lying after he had purportedly undergone a moral transformation and decided to change his ways, his entire testimony may have been rejected by the jury. It was one thing for the jury to learn that Guariglia had a history of improprieties; it would have been an entirely different matter for them to learn that after having taken an oath to speak the truth he made a conscious decision to lie. While the jury was instructed that Moreno was an acknowledged perjurer whose testimony should be weighed carefully, no such instruction was given relative to Guariglia's testimony. Accordingly, because we are convinced that the government should have known that Guariglia was committing perjury, all the convictions must be reversed.

Id. at 457 . The importance of cooperating witnesses makes it imperative for prosecutors to ensure that they are telling the truth to avoid having a conviction overturned because of negligence on their part. 
larger mosaic presented through the witness. What does a lawyer do when the witness-and perhaps even the client-starts adding details that had not come up during trial preparation to make the testimony potentially more persuasive? ? $^{58}$ When is the line between inevitable minor errors of recall and perjury crossed?

One potential safeguard can give an attorney some comfort if this occurs: cross-examination. Wigmore's famous phrase about cross-examination is that it is "the greatest legal engine ever invented for the discovery of truth." opponent should be able to expose the inconsistencies in the testimony through a clever examination of the falsifying witness, thus strengthening that side's case by undermining the credibility of the opponent. For the cooperating witness, in all likelihood one or more reports of earlier interviews exist that can be used to cross-examine, although these reports may not be very thorough or may not address all the points that a witness testified about. The report is that of an agent, not the witness, so its utility in cross-examination may be limited. ${ }^{60}$ For the testifying defendant, a report recounting a prior meeting is less likely to be available, although if the person agreed to be interviewed early on in the investigation there may be recorded statements that can be used.

Cross-examination may not be the great legal engine espoused by Wigmore, especially in a federal criminal prosecution which does not include open discovery and in which the preparation sessions between a witness and the lawyer are not necessarily subject to any outside scrutiny. Although some prosecutors use the "open file" discovery method, ${ }^{61}$ not all do, and from the government's

58. See Gershman, supra note 7, at 835 ("A major incentive for prosecutors to use cooperating witnesses is to support an uncertain but consistent version of the facts, rather than to confirm an inconsistent version of the facts that may represent more of the truth.").

59. 5 John Henry Wigmore, EvidenCe In Trials At Common Law § 1367 (J. Chadbourn rev. 1974).

60. Under Federal Rule of Criminal Procedure 26.2, the government must produce a "statement" made by any of its witnesses, which is defined to include "a written statement that the witness makes and signs, or otherwise adopts or approves" or "a substantially verbatim, contemporaneously recorded recital of the witness's oral statement that is contained in any recording or any transcription of a recording." FED. R. CRIM. P. 26.2(f)(1)-(2). If the interview notes are those of an agent that do not purport to be a verbatim recital of the witness's statement or is not adopted by the witness, then it need not be produced to the defense. See United States v. Bobadilla-Lopez, 954 F.2d 519, 522 (9th Cir. 1992) ("Both the history of the statute and the decisions interpreting it have stressed that for production to be required, the materials should not only reflect the witness' own words, but should also be in the nature of a complete recital that eliminates the possibility of portions being selected out of context.").

61. As the name implies, open file discovery is when the prosecutor supplies all information related to a case, except for privileged communications and work product, to the defendant in advance of trial. One advantage of this approach is that it avoids having the prosecutor determine what evidence constitutes Brady material because all documents are provided, regardless of whether they are inculpatory or exculpatory. See Robert $P$. Mosteller, Exculpatory Evidence, Ethics, and the Road to the Disbarment of Mike Nifong: The Critical Importance of Full Open-File Discovery, 15 GEO. MASON L. REv. 257, 310 (2008) ("The beauty of full open-file discovery is obvious as a remedy for the difficulty of subjective choice in a competitive adversarial environment. It does not require a prosecutor to make difficult discretionary decisions."). 
perspective it has no access to the defendant once charges are filed. ${ }^{62}$ Putting the onus on the opponent to ferret out any falsity in a witness's testimony may not be the best method of preventing a violation of Model Rule 3.3, which does not prohibit the introduction of false testimony "unless you can get away with it."

The lack of access to information about witness preparation is exacerbated for the defense lawyer because it is in the client's interest to allow the testimony to go forward in the hope that the jury will return a not guilty verdict. As one lawyer put it very aptly, "a trial may be a search for truth, but I-as a defense attorney-am not part of the search party." 63 If the testimony does not reach the level of falsity outlined in Nix, and perhaps even if it does, then there is a question of whether defense counsel has an obligation under the professional conduct rules to intervene or even disclose it to the court. ${ }^{64}$

When the lawyer does not know what the truth actually is, then what should the person do about a client or witness who is a very good liar? If someone is able to testify convincingly, even if the lawyer questions the testimony's truth, it may be permissible to have the witness testify. Model Rule 3.3 prohibits a lawyer from "knowingly" offering false evidence, which means the attorney must have actual knowledge and not just a suspicion. ${ }^{65}$ The age-old issue is, when does a lawyer really know the witness or client is not testifying truthfully? Even the strict prohibition on using false evidence is mitigated in the Model Rules if the lawyer does not reach the level of actual knowledge, and the Comment to Rule 3.3 states that "[a] lawyer's reasonable belief that evidence is false does not preclude its presentation to the trier of fact." ${ }^{, 66}$ The drafters try to mitigate this by further

62. The Fifth Amendment privilege against self-incrimination prevents the government from calling a defendant to testify at trial, and the prosecution cannot comment on a defendant's decision not to testify. See Griffin v. California, 380 U.S. 609, 615 (1965) ("[T]he Fifth Amendment, in its direct application to the Federal Government and in its bearing on the States by reason of the Fourteenth Amendment, forbids either comment by the prosecution on the accused's silence or instructions by the court that such silence is evidence of guilt."). Prior to trial, a person cannot be forced to testify against himself in a police interrogation, before a grand jury, or even in a civil proceeding if the answer may be incriminating. See Pillsbury Co. v. Conboy, 459 U.S. 248, 266 n.1 (1983) ("A witness is generally entitled to invoke the Fifth Amendment privilege against selfincrimination whenever there is a realistic possibility that his answer to a question can be used in any way to convict him of a crime. It need not be probable that a criminal prosecution will be brought or that the witness's answer will be introduced in a later prosecution; the witness need only show a realistic possibility that his answer will be used against him. Moreover, the Fifth Amendment forbids not only the compulsion of testimony that would itself be admissible in a criminal prosecution, but also the compulsion of testimony, whether or not itself admissible, that may aid in the development of other incriminating evidence that can be used at trial.").

63. Gerald L. Shargel, Federal Evidence Rule 608(b): Gateway to the Minefield of Witness Preparation, 76 FoRdHAM L. REv. 1263, 1267 (2007).

64. Model Rule 3.3(a)(3) prohibits offering evidence the lawyer "knows to be false." MODEL RULES R. 3.3(a)(3). If the lawyer does not know it is false because it is not clear that the testimony is in fact incorrect, then the obligation not to introduce the evidence is not triggered.

65. Model Rule $1.0(f)$ provides that “'[k]nowingly,' 'known,' or 'knows' denotes actual knowledge of the fact in question." MODEL RULES R. 1.0(f). The actual knowledge standard means that even a reasonable suspicion would not constitute the requisite knowledge to trigger the prohibition of Model Rule 3.3(a)(3).

66. Model Rules R. $3.3 \mathrm{cmt}$. I [8]. 
stating that "although a lawyer should resolve doubts about the veracity of testimony or other evidence in favor of the client, the lawyer cannot ignore an obvious falsehood." The distinction appears to be one between a "mere" falsehood-something a teenager might call a "kinda lie"-and one that is clearly false.

\section{CONCLUSION}

Public corruption cases are among the most significant that federal prosecutors pursue because of their impact on society. For the public official, even an accusation of corruption can end a career, ${ }^{67}$ and a conviction means that the person in all likelihood will never again be trusted with public office. The trial in this type of case hinges on proving the transaction at issue was "corrupt" and not just an acceptable interaction between an official and members of the public. The testimony of witnesses, most importantly the defendant and any participant in the allegedly corrupt exchange who agrees to cooperate, will be the focal point of the trial. Thus, preparing these witnesses for trial is crucial.

While courts and the professional responsibility rules acknowledge the importance of witness preparation, they do little to identify when an attorney crosses the line into creating (or allowing) false testimony. Even the most scrupulous lawyer cannot protect against a witness embellishing on the witness stand, but the dilemma is what to do when that happens. While the rule is clear that false testimony is impermissible, that begs the question of what constitutes "false."

I will not pretend to offer any proscriptions that will solve the issue of when testimony is false, or what a lawyer is required to do in a particular situation. The professional responsibility rules put the onus on the individual lawyer to decide what to do, and there is no set of guidelines that can be provided for judging how far witness preparation can go or to say when testimony crosses the line into falsity and perhaps even perjury. It is ultimately the lawyer's personal sense of propriety - the individual's moral compass - that will determine what is appropriate.

67. Public corruption investigations occasionally have the public official who is the target voluntarily testify before the grand jury in an attempt to forestall an indictment, a risky proposition, and one rarely tried in other types of white collar criminal investigations. 